\title{
Early period psychiatric disorders following burn trauma and the importance of surgical factors in the etiology
}

\author{
Yanık travması sonrası erken dönemde görülen psikolojik bozukluklar ve \\ etyolojide cerrahi faktörlerin yeri
}

\author{
Hakan YABANOĞLU, ${ }^{1}$ Mahmut Can YAĞMURDUR, ${ }^{1}$ \\ Nilgün TAŞKINTUNA, ${ }^{2}$ Hamdi KARAKAYALI ${ }^{1}$
}

\section{BACKGROUND}

We aimed to assess early period psychiatric disorders following burn trauma.

\section{METHODS}

The files of 1369 patients who had burn trauma were analyzed retrospectively. Forty-five patients with the diagnosis of psychiatric disorder were assessed based on the variables of age, gender, presence of chronic diseases, psychiatric disorders prior to burn trauma, cause of the burn, burn percentage, degree of burn, additional trauma, number of surgeries, duration of hospitalization, extremity amputation, intubation status, psychiatric symptoms, post-trauma psychiatric disorders, and mortality.

\section{RESULTS}

Forty-five patients developed psychiatric disorder in the early period following burn trauma. Of the 45 patients, $7(15.5 \%)$ were female and $38(84.5 \%)$ were male. The mean age was $32 \pm 14.3$ years, burn percentage was $40.09 \pm 20.69 \%$, number of operations was $2.95 \pm 1.75$, and the total duration of hospitalization was $51.57 \pm 38.62$ days. Twelve (26.6\%) patients had post-traumatic stress disorder (PTSD), 11 (24.4\%) had delirium, 8 (17.7\%) had anxiety disorder, 7 (15.5\%) had depression, 1 (2.2\%) had abstinence syndrome, $1(2.2 \%)$ had schizoaffective disorder, 2 (4.4\%) had PTSD and depression, 2 (4.4\%) had PTSD and delirium, and $1(2.2 \%)$ had PTSD and anxiety disorder.

\section{CONCLUSION}

Burn is a trauma that can be treated with a multidisciplinary approach.

Key Words: Burns; early diagnosis; psychiatric disorder.

\section{$A M A C$}

Yanık travması sonrasında erken dönemde ortaya çıkan psikiyatrik bozukluklar değerlendirildi.

\section{GEREÇ VE YÖNTEM}

Yanık travmasına maruz kalan 1369 hastanın dosyası geriye dönük olarak incelendi. Psikiyatrik bozukluk saptanan 45 hasta yaş, cinsiyet, kronik hastalık, yanık öncesindeki psikiyatrik bozukluk, yanık nedeni, yanık yüzdesi, yanık derecesi, ek travma, ameliyat sayısı, hastanede kalış süresi, ekstremite amputasyonu, entübasyon durumu, psikiyatrik semptomlar, travma sonrası psikiyatrik bozukluk ve mortalite açısından değerlendirildi.

\section{BULGULAR}

Yanık travması sonrası erken dönemde 45 hastada psikiyatrik bozukluk saptandı. Hastaların 7'si (\%15,5) kadın, 38 'i $(\% 84,5)$ erkekti. Ortalama yaş $32 \pm 14,3$ yıl, yanık yüzdesi $\% 40,09 \pm 20,69$, geçirilmiş ameliyat sayıs $2,95 \pm 1,75$, hastanede kalış süresi $51.57 \pm 38.62$ gün idi. Hastaların 12 'sinde $(\% 26,6)$ post travmatik stres bozukluğu (PTSD), 11 'inde $(\% 24,4)$ deliryum, 8 'inde $(\% 17,7)$ anksiyete bozukluğu, 7 'sinde $(\% 15,5)$ depresyon, 1 'inde $(\% 2,2)$ yoksunluk sendromu, 1 'inde (\%2.2) şizoaffektif bozukluk, 2 'sinde $(\% 4,4)$ PTSD ve depresyon, 2 'sinde $(\% 4,4)$ PTSD ve deliryum ve 1 'inde (\%2.2) PTSD ve anksiyete bozukluğu görüldü.

\section{SONUÇ}

Yanık multisipliner yaklaşımla tedavi edilebilen bir travmadir.

Anahtar Sözcükler: Yanık; erken tanı; psikiyatrik bozukluk.
Departments of ${ }^{1}$ General Surgery, ${ }^{2}$ Psychiatry, Baskent University Faculty of Medicine, Ankara, Turkey
Başkent Üniversitesi Tıp Fakültesi, ${ }^{1}$ Genel Cerrahi Anabilim Dalı, ${ }^{2}$ Psikiyatri Anabilim Dall, Ankara. 
Burn is one of the most important physical and psychological traumas that an individual can experience in his life. Burn trauma carries high morbidity and mortality rates due to numerous causes such as hypovolemic shock, infection and concurrent additional traumas. Due to the social and psychological problems associated with burn trauma, it has gone beyond being solely a physical trauma and has evolved into a serious problem that has a significant influence on the individual's life. Especially in recent years, there have been serious advancements in burn treatment due to the increased quality of medical care, development of broad-spectrum antibiotics that are also effective on burn infections, improved intensive care conditions for burn patients, increased experience among physicians and supportive health personnel in burn trauma, patient referrals, nutritional support, early debridement and grafting, tissue production, and multidisciplinary approaches. Mortality and morbidity rates due to burn complications have diminished with the advancements in burn treatment. Because of high mortality rates and high costs, the best treatment option in burn trauma is prevention. The increased lifespan of patients with burn traumas has increased the need for rehabilitation and psychosocial treatment options for burn. ${ }^{[1]}$

In patients with burn trauma, the initial choice of treatment is local and systemic treatment of the burned tissue. However, during the prolonged treatment period, psychological factors will also appear to be influential on treatment. Especially in patients who are hospitalized for extended periods, who have undergone numerous operations, have severe pain during medical dressing, have permanent physical and functional tissue loss, and have permanent labor loss, treatment compliance would decrease over time. This underlines the importance of providing psychological support in addition to physical support to the patient. Prevalence of psychiatric disorders in burn patients is between $28-75 \%{ }^{[2,3]}$ Psychological disorders observed most frequently during the early period following the burn trauma include acute stress reactions, anxiety disorder, depression, behavioral disorders, and delirium. ${ }^{[4]}$

Psychological disorders observed in hospitalized patients depend on the events occurring both during the trauma itself and during treatment approaches. Physical and psychological trauma in these patients should be treated medically and surgically for a long period of time. If patients are only treated physically, physiological disorders can emerge during the late period of treatment and this may disturb the patient's attendance and cooperation with therapy, causing an increment in the patient's hospital stay, morbidity and mortality rates, and costs. The aim of this study was to diagnose and treat the psychological disorders in the early period of burn trauma in order to prevent later medical and sociological complications and to identify the surgical factors causing psychological disorders to emerge.

\section{MATERIALS AND METHODS}

In this study, the files of 1369 patients who were hospitalized at the Burn Intensive Care Unit (ICU) of the Burn and Fire Incidents Institute of Ankara Başkent University between October 1997 and July 2011 were analyzed retrospectively for psychiatric disorders emerging in the first 15 days of hospitalization. Forty-five patients who were found to have psychiatric disorders were assessed based on the variables of psychiatric disorders prior to burn trauma, cause of the burn, burn percentage, degree of burn, additional trauma, number of surgeries, duration of hospitalization, extremity amputation, intubation status, psychiatric symptoms, post-trauma psychiatric disorders, and mortality. Surgical factors that might cause psychiatric disorders were studied. The Statistical Package for the Social Sciences (SPSS, version 11.5) software program was used for data analysis in a computer environment.

\section{RESULTS}

In this study, we analyzed retrospectively the case files of 1369 patients. As a result of the analysis, 45 (3.2\%) patients had psychiatric disorder accompanying the burn trauma. Of the 45 patients, $7(15.5 \%)$ were female and $38(84.5 \%)$ were male. The average age of the patients was $32 \pm 14.3(8-80)$ years, burn percentage was $40.09 \pm 20.69 \%$ (5-85), number of operations was $2.95 \pm 1.75(0-9)$, and the total duration of hospitalization was $51.57 \pm 38.62$ (2-180) days. Seventeen (37\%) patients had only 2 nd degree deep burn, $2(4.4 \%)$ had only 3 rd degree, and 26 (58\%) had 2nd degree deep and 3rd degree burn. When the mechanism of burn was considered, 32 (71\%) were flame burn, 11 (24\%) were electricity burn and $2(4.4 \%)$ were hot water scald burn (4.4\%). With regard to chronic diseases, 1 patient had diabetes mellitus (DM), 1 had hypertension (HT), 1 had DM, HT and chronic obstructive lung disease, and 1 had epilepsy. Six (13.3\%) patients underwent extremity amputation in addition to debridement and grafting. None of the patients had a history of additional traumas. Twelve $(26.6 \%)$ patients were administered tracheal intubation at different times during their hospitalization. An analysis of the psychiatric diagnosis prior to the trauma revealed that 1 patient had alcohol addiction, 2 had depression, 1 had anxiety disorder, 1 had schizoaffective disorder, and 1 had hyperactivity disorder. Distribution of the patients' demographic characteristics and the data obtained based on the process of burn formation are given in Table 1. An analysis of the psychiatric disorders in the early period after the burn trauma showed that $12(26.6 \%)$ 
Table 1. Distribution of patients according to demographic characteristics and mechanism of burn

\begin{tabular}{lccc}
\hline Mechanism of burn & $\begin{array}{c}\text { Electrical } \\
\text { burns }\end{array}$ & $\begin{array}{c}\text { Flame } \\
\text { burns }\end{array}$ & $\begin{array}{c}\text { Scald } \\
\text { burns }\end{array}$ \\
\hline $\begin{array}{l}\text { Number of patients } \\
\begin{array}{l}\text { Sex } \\
\text { Number of amputated } \\
\text { patients }\end{array}\end{array}$ & $11 \mathrm{M}$ & $\begin{array}{c}32 \\
25 \mathrm{M} / 7 \mathrm{~F}\end{array}$ & $\begin{array}{c}2 \mathrm{M} \\
\text { Number of intubated } \\
\text { patients }\end{array}$ \\
$\begin{array}{l}\text { Number of patients } \\
\text { with psychiatric } \\
\text { disorders pre-trauma }\end{array}$ & 3 & 3 & 0 \\
$\begin{array}{l}\text { Most common } \\
\text { psychiatric } \\
\text { diagnosis }\end{array}$ & Delirium & PTSD & SD, WS \\
\hline
\end{tabular}

PTSD: Post-traumatic stress disorder; SD, WS: Schizoaffective disorder and withdrawal syndrome; M: Male; F: Female.

Table 2. General distribution of psychiatric disorders in the early period after burn

\begin{tabular}{lc}
\hline Psychiatric diagnosis & Number of patients \\
\hline PTSD & $12(26.6 \%)$ \\
Delirium & $11(24.4 \%)$ \\
Anxiety disorder & $8(17.7 \%)$ \\
Depression & $7(15.5 \%)$ \\
PTSD + Depression & $2(4.4 \%)$ \\
PTSD + Delirium & $2(4.4 \%)$ \\
PTSD + Anxiety disorder & $1(2.2 \%)$ \\
Withdrawal syndrome & $1(2.2 \%)$ \\
Schizoaffective disorder & $1(2.2 \%)$ \\
\hline
\end{tabular}

PTSD: Post-traumatic stress disorder.

patients had post-traumatic stress disorder (PTSD), 11 (24.4\%) had delirium, 8 had (17.7\%) anxiety disorder, $7(15.5 \%)$ had depression, $1(2.2 \%)$ had abstinence syndrome, $1(2.2 \%)$ had schizoaffective disorder, 2 (4.4\%) had PTSD and depression, 2 (4.4\%) had PTSD and delirium, and $1(2.2 \%)$ had PTSD and anxiety disorder (Table 2). The most frequent psychiatric symptoms observed in patients included sleep disorder, agitation, and visual and auditory hallucinations. Two (4.4\%) patients died due to sepsis and 1 patient $(2.2 \%)$ due to pneumonia.

\section{DISCUSSION}

Burn trauma, affecting the entire organism and causing pathophysiological and psychological disorders, must be evaluated comprehensively. Burns, causing mortality and morbidity, are serious problems for people and society. In advanced burn units, mortality in major burns is $5.6 \%$, and in Turkey it is reported as $7.5 \%{ }^{[5-8]}$ In the United States, treatment cost of a patient with major burns was reported as $\$ 200,000$. The cost of the treatment of entire burn cases is 18 billion dollars per year. ${ }^{[6]}$

Having both serious physical and psychological implications, burn trauma brings about not only serious medical problems but serious psychological problems as well. With the advancement of medical services and rehabilitation services geared towards burn patients, survival rates have increased. All these developments have carried psychiatry to a new level with regard to a multidisciplinary approach to burn trauma. The medical and surgical treatment of the patient is no longer the ultimate goal and providing psychiatric support to the patient has become an indispensible part of treatment during both the hospitalization period and the patient's social life after discharge from the hospital. Especially complaints of severe pain, repeated medical dressing procedures and operations during the hospitalization period, cosmetic anxieties, permanent loss of labor skills, permanent limitation or loss of mobility, communication disorder, and extended periods of hospitalization often manifest themselves as psychiatric disorders. Failure to detect and treat these psychiatric disorders in a timely manner would decrease the patient's compliance with medical and surgical treatment. A review of the literature reveals that the studies conducted have focused in general on parameters such as the types and prevalence of psychiatric disorders, their short-term and long-term follow-up, pre-existing psychiatric disorders, and gender ${ }^{[9-13]}$ In this study, in addition to these variables, the authors have also focused on other factors that they believed might be influential in causing these disorders, such as burn percentage, degree of burn, the process of burn formation, intubation status, amputation, total number of operations, and duration of hospitalization. An analysis of the results reveals that the patients face a very serious trauma. A review of the files of all patients shows that burn percentage in the patient group for which consultation was requested $(3.2 \%)$ was $40 \%$, burn degree was at least 2 nd degree deep burn, the average number of operations was 3 , and the average hospitalization duration was 51 days. Intubation $(26.6 \%)$ and amputation $(13.3 \%)$ rates were found to be higher than those for the general patient population. All parameters analyzed indicated a more severe trauma than that observed in the general patient population. It is inevitable for such an intense physical trauma to have psychiatric outcomes in both the shortand long term. During this period of time, the important point is to utilize that time to ensure the least damage with the help of appropriate psychological support from the beginning of trauma and at all stages.

Recently, there has been a rise in the number of studies assessing the psychological and mental status 
of burn patients. Prevalence of psychiatric disorders in burn patients is between $28-75 \% \cdot{ }^{[2,3]}$ In our study, this rate was found to be $3.2 \%$. In fact, the number of patients treated at our burn ICU between 1997 and 2007 was 1167, and a psychiatric consultation was requested for only 24 of them (2.1\%). Psychiatric consultation was requested for only $21(10.3 \%)$ of the 202 patients treated between 2007 and 2011. And overall, consultation was requested for $45(3.2 \%)$ of the 1396 patients. It is noteworthy that burn treatment has reached an advanced level owing to the developments in the medical and surgical fields and that survival rates have increased. These findings have motivated practitioners to evaluate the psychological aspects of the trauma and adopt a multidisciplinary approach to burn trauma. In our clinic, the number of burn trauma patients who go through psychiatric assessment also increases in parallel to our increased experience in this field. Nevertheless, this rate is far below that in the literature. One of the reasons for this is that around 30\% of the patients in our burn ICU are pediatric patients. Among the other reasons are the facts that the number of burn ICUs in our country is limited, the number of patients referred to our center is high, and a portion of these patients had intubation, a high burn rate or mortality in the early period; thus, it was not possible to provide the required psychiatric support to these patients.

In burn trauma, handled and treated by most surgeons as only physical trauma, it must be kept in mind that burn trauma also has social and psychological elements. The treatment process may be accelerated for both patient and physician with psychological support in the early period. By this process, mortality and morbidity of burn, a serious social trauma, will decrease. Especially for patients with major burns, psychological support must be applied routinely as a part of medical and surgical approaches.

The most frequent psychiatric disorders observed in burn patients are PTSD (5-45\%) and depression $(13-23 \%) .{ }^{[4,10,14,15]}$ While the rate of depression after the burn incident was $2.2-53 \%$ during the first month, this ratio was $13-34 \%$ during the 12 th month. On the other hand, while the frequency of PTSD in the early period was $2.2-26 \%$, this ratio was $13-45 \%$ during the 12th month. ${ }^{[16-21]}$ Risk factors for depression include presence of depression prior to the burn incident, female gender and scars causing deformations in the face. Risk factors for PTSD include presence of depression prior to the burn incident, type and severity of the symptoms at the onset, presence of pain-related anxiety, and visibility of the burn scar. ${ }^{[22]}$ In our study, $12(26.6 \%)$ patients were found to have PTSD, 11 $(24.4 \%)$ delirium and $7(15.5 \%)$ depression. These findings were consistent with those in the literature.
Three of our patients diagnosed with depression were female, and only 1 patient was diagnosed with depression prior to the trauma. Of those patients with the diagnosis of PTSD, only 1 of them had anxiety disorder prior to the trauma. Burn rates of 12 patients who were diagnosed with PTSD were $20-85 \%$. Of these patients, 4 had 2nd degree deep burn, 1 had 3rd degree burn and 9 had 2 nd and 3rd degree burn. Overall, it was observed that the burn rates of patients are high and that the related pain symptoms are excessive. The most common psychiatric symptom observed in PTSD patients was sleep disorder. The studies reveal that people with personality disorders, depression and alcohol and substance addiction become subject to burn traumas more often than individuals in the general population. Probability of observing a psychiatric disorder in patients prior to the burn trauma is $28-78 \%{ }^{[2,3]}$ Six $(13.3 \%)$ of our patients were previously diagnosed with a psychiatric disorder. In another study, a psychiatric disorder was diagnosed in $38.9 \%$ of the patients following the burn trauma; however, it was also found that a psychiatric disorder caused by trauma was observed in only $27.8 \%$ of these patients and that other patients had psychiatric disorders prior to the trauma as well. ${ }^{[13]}$ Problems related to patience compliance and cooperation are commonly observed during the hospitalization process of these patients. These problems delay physical recovery and prolong the hospitalization period. ${ }^{[4]}$ Psychological problems experienced in the early period following the burn trauma include overstimulation or sub-threshold stimulation, delirium, confusion, communication disorder, and sleep disorder. In our study, the most frequently observed symptoms included sleep disorder, agitation, and visual and auditory hallucinations.

The treatment process that is started following a burn trauma is one of the most painful and stressful experiences that a patient may experience. Medical interventions made during the treatment and aimed at helping the patient survive most often disregard the psychological support that should be given to the patient. Psychological disorders observed in patients are usually not limited to the hospitalization period and continue to be observed even many years after the treatment. ${ }^{[9,13]}$ Regardless of how well the patients may be functionally and cosmetically, they should be provided psychiatric support in order to be able to adapt themselves to social life, regain their self-esteem and overcome the psychological effects of the trauma.

The results and sequelae of burn trauma have a great importance both for the individual society. Burn causes functional losses and social and psychological problems in the early and late healing period. The best treatment of burn is prevention. Individuals and institutions must take good care of themselves and 
other individuals with respect to the prevention of burn. It must be kept in mind that burn is a preventable trauma; thus, effective burn prevention education programs must be developed or improved.

In conclusion, burn is a trauma that can be treated with a multidisciplinary approach. Psychiatric consultation should be requested as soon as possible for patients who refer to the burn ICU and who have high burn percentages and degrees, are candidates for multiple surgery, have a history of psychiatric diseases, and have extended periods of hospitalization. Surgical and medical treatment by itself is not sufficient for the treatment of burn patients. Psychiatric problems experienced by patients both during and after the trauma should always be considered. Patients and their families should seek professional support from psychiatrists. This would both improve patient compliance and expedite the process for the patient to resume his/her social life. Surgeons who play an important role in the surgical and medical treatment of burn patients should keep in mind that these patients will require psychological support as well.

\section{REFERENCES}

1. Munster AM. Measurements of quality of life: then and now. Burns 1999;25:25-8.

2. Brezel BS, Kassenbrock JM, Stein JM. Burns in substance abusers and in neurologically and mentally impaired patients. J Burn Care Rehabil 1988;9:169-71.

3. Davidson TI, Brown LC. Self-inflicted burns: a 5-year retrospective study. Burns Incl Therm Inj 1985;11:157-60.

4. Patterson DR, Everett JJ, Bombardier CH, Questad KA, Lee VK, Marvin JA. Psychological effects of severe burn injuries. Psychol Bull 1993;113:362-78.

5. Monafo WW. Initial management of burns. N Engl J Med 1996;335:1581-6.

6. Patel PP, Vasquez SA, Granick MS, Rhee ST. Topical antimicrobials in pediatric burn wound management. J Craniofac Surg 2008;19:913-22.

7. O'Brien SP, Billmire DA. Prevention and management of outpatient pediatric burns. J Craniofac Surg 2008;19:1034-9.

8. Gomez M, Cartotto R, Knighton J, Smith K, Fish JS. Improved survival following thermal injury in adult patients treated at a regional burn center. J Burn Care Res 2008;29:130-7.

9. Palmu R, Suominen K, Vuola J, Isometsä E. Psychiatric consultation and care after acute burn injury: a 6-month naturalistic prospective study. Gen Hosp Psychiatry 2011;33:16-22.

10. Lu MK, Lin YS, Chou P, Tung TH. Post-traumatic stress disorder after severe burn in southern Taiwan. Burns 2007;33:649-52.

11. Ehde DM, Patterson DR, Wiechman SA, Wilson LG. Posttraumatic stress symptoms and distress following acute burn injury. Burns 1999;25:587-92.

12. Dyster-Aas J, Willebrand M, Wikehult B, Gerdin B, Ekselius L. Major depression and posttraumatic stress disorder symptoms following severe burn injury in relation to lifetime psychiatric morbidity. J Trauma 2008;64:1349-56.

13. Ter Smitten MH, de Graaf R, Van Loey NE. Prevalence and co-morbidity of psychiatric disorders 1-4 years after burn. Burns 2011;37:753-61.

14. Yu BH, Dimsdale JE. Posttraumatic stress disorder in patients with burn injuries. J Burn Care Rehabil 1999;20:42633.

15. Fauerbach JA, Lawrence JW, Munster AM, Palombo DA, Richter D. Prolonged adjustment difficulties among those with acute posttrauma distress following burn injury. J Behav Med 1999;22:359-78.

16. Tedstone JE, Tarrier N. An investigation of the prevalence of psychological morbidity in burn-injured patients. Burns 1997;23:550-4.

17. Wiechman SA, Ptacek JT, Patterson DR, Gibran NS, Engrav LE, Heimbach DM. Rates, trends, and severity of depression after burn injuries. J Burn Care Rehabil 2001;22:417-24.

18. Maes M, Mylle J, Delmeire L, Altamura C. Psychiatric morbidity and comorbidity following accidental man-made traumatic events: incidence and risk factors. Eur Arch Psychiatry Clin Neurosci 2000;250:156-62.

19. Van Loey NE, Maas CJ, Faber AW, Taal LA. Predictors of chronic posttraumatic stress symptoms following burn injury: results of a longitudinal study. J Trauma Stress 2003;16:3619.

20. Williams EE, Griffiths TA. Psychological consequences of burn injury. Burns 1991;17:478-80.

21. Difede J, Barocas D. Acute intrusive and avoidant PTSD symptoms as predictors of chronic PTSD following burn injury. J Trauma Stress 1999;12:363-9.

22. Çakır S, Kulaksızoğlu BI. Psychological support of burn injury patients and burn unit staff. Turkiye Klinikleri J Surg Med Sci 2007;3:116-20. 